\title{
Crise do capital, neoconservadorismo e Serviço Social no Brasil: apontamentos para o debate
}

\author{
The crisis of capitalism, neoconservatism and social work in \\ Brazil: notes for debate
}

José Fernando Siqueira da Silva*

\begin{abstract}
Resumo - O artigo apresentado oferece apontamentos críticos para o debate sobre as expressões do neoconservadorismo no Serviço Social brasileiro no atual estágio de acumulação do capital. O texto, inspirado no ponto de vista da totalidade, radicalmente histórico e vinculado às condições impostas por determinada historicidade (Marx-Lukács), indica tendências teórico-práticas atuais no campo particular do Serviço Social. Faz isto certamente sem qualquer traço endógeno e abstrato, ressaltando a reconstrução mental de uma dinâmica contida no movimento da própria realidade. Analisar como essa profissão e os assistentes sociais estão se inserindo nessa complexidade materialmente posta, historicamente vinculada à sua gênese como profissão, é condição básica para reafirmar sua inserção crítico-propositiva nessa realidade.

Palavras-chave: serviço social; neoconservadorismo; projeto éticopolítico profissional.
\end{abstract}

\begin{abstract}
This article presents critical notes for discussion on expressions of neoconservatism in Brazilian social work in the present state of capital accumulation. It is, as a whole, radically historical and bound to conditions imposed by a given historicity (Marx-Lukács), and indicates current theoretical practical tendencies in the field of social work. The approach is not endogenous-abstract, emphasizing the mental reconstruction of the dynamics of reality itself. Our conclusions indicate that it is imperative for social workers to analyze their own profession, for their constructive critical insertion on the existing material complexity - which is historically bound to the genesis of the profession.
\end{abstract}

Keywords: social work; neoconservatism; professional ethical-political project.

\footnotetext{
*Assistente Social. Doutor em Serviço Social pela PUC e livre-docente em Serviço Social pela UNESP. Professor colaborador da proposta APCN-2015 apresentada pela Universidade Federal de São Paulo (UNIFESP) à área de Serviço Social da CAPES (curso: Política Social e Serviço Social). Correspondência: Rua Rio Japurá, 1377, Franca, SP. CEP 14406-034. E-mail: <jfernandoss@terra.com.br>
} 


\section{Observações iniciais: situando o debate}

Debater a inserção profissional dos assistentes sociais nos espaços sócio-ocupacionais propiciados pelo capitalismo na sua fase madura é de grande relevância à área de Serviço Social. Mais do que simplesmente descrever ou destacar experiências pontuais vivenciadas por assistentes sociais em tempos "neoliberais", trata-se de perquirir a trama que constitui o trabalho profissional $^{1}$ no campo particular do Serviço Social, tecida em uma fase determinada do capitalismo monopolista, inspirada no padrão toyotista de organização/racionalização da força de trabalho, potencializada pela intensa financeirização (HARVEY, 2011; CHESNAIS, 1996; IAMAMOTO, 2007). No caso brasileiro e latino-americano, é preciso considerar o traço hipertardio e dependente que marcou todos os países que objetivaram suas revoluções burguesas - certamente com particularidades nada desprezíveis - já sob as condições do século XX (FERNANDES, 1987; 2009). Sem essas importantes observações, o termo "neoliberal" se perde na abstração, como um "jargão que responde a tudo" (ou quase tudo), e se mostra incapaz de destacar as particularidades do capitalismo de monopólios nas últimas três décadas do século XX.

Impensável sem o capitalismo a partir de sua fase monopólica e fundado no campo contraditório de lutas entre capital e trabalho, o Serviço Social tem sua gênese como profissão atrelada às múltiplas estratégias materialmente tecidas para a gestão do pauperismo. Foi a partir desse contexto que esta profissão nasceu, institucionalizou-se, consolidou-se no mercado de trabalho e vem se reatualizando, teórica e praticamente, seja para modernizar o legado conservador ou, ao contrário, com todos os limites objetivamente dados, questioná-lo. As lutas travadas durante o processo de reconceituação latino-americano (1965-1975 - não exatamente), de renovação do Serviço Social brasileiro (especialmente no que foi denominado por Netto - 1991 como "intenção de ruptura"), as duas últimas revisões do Código de Ética Profissional realizadas nos anos 1980 e 1990, as inúmeras lutas sociais a que se vincularam os assistentes sociais nas últimas décadas e as discussões sobre o que vem sendo denominado Projeto Ético-Político Profissional (como direção social estratégica) reafirmaram o legado crítico no âmbito particular do Serviço Social brasileiro.

Há, todavia, nos dias atuais, a necessidade de clarear o sentido dessa direção social construída no debate profissional, perspectiva esta certamente comprometida com níveis crescentes de emancipação social. Ao contrário de desqualificar tal orientação, reconhecer a necessidade de explicá-la nas condições atuais tem o exato sentido de trazer à tona problemas materiais-concretos para afirmá-la como direção social possível e válida nos dias atuais. Essas tensões são inseridas e inseparáveis da crise estrutural

${ }^{1}$ Ver: lamamoto (2007) e Silva (2013a; 2013b). 
do capital, da insustentabilidade do capitalismo como ordem social necessária à sua produção e reprodução ampliada (MÉSZÁROS, 2002). Isso tem se expressado significativamente nas tendências teórico-metodológicas em curso no Serviço Social brasileiro e influenciado no trabalho profissional.

O que se discute aqui, então, é que tal direção social crítico-estratégica vem sendo impactada por condições objetivas adversas, bem como está articulada ao entendimento que os assistentes sociais estão formando sobre os princípios e as categorias sociais contidos nesse "projeto", que dão vida e conteúdo teórico-prático, ético-político e técnico-instrumental a ele: cidadania, emancipação, liberdade, democracia, justiça e equidade social - (por exemplo). Em outras palavras, a apreensão equivocada acerca dessa direção social e de seus princípios, em um momento histórico mais favorável às imposições do capital ao trabalho, não apenas põe em cheque a sua proposta como também a quebra medularmente ao acomodá-la e docilizá-la aos limites da propriedade privada.

Afirmar esse Projeto Ético-Político Profissional hoje supõe, necessariamente, radicalizar (no sentido marxiano - MARX, 2005) a explicação desses princípios e categorias como direção organicamente vinculada a projetos societários amplos, capazes de organizar formas de resistência e fomentar alternativas de defesa do ponto de vista do trabalho útil, concreto, genuinamente humano e potencializador da emancipação humana (MARX, 2009). Isso supõe, ao mesmo tempo, a adoção de alternativas que articulem esses princípios à esfera particular do Serviço Social como profissão, com seus limites objetivos como tais, o que não deve significar, em hipótese alguma, uma imposição de "tarefas" que não podem ser realizadas pelo Serviço Social e por qualquer outra profissão, mas que, por outro lado, devem iluminar a práxis profissional como referência geral. Ora, tais princípios, também situados no campo da emancipação política, têm se mostrado insustentáveis sob o mando da sociabilidade burguesa madura, regido pela propriedade privada, reduzindo e eliminando brutalmente direitos.

Reafirmar na atualidade o Projeto Ético-político Profissional elaborado nos anos 1990 e a predominância hegemônica de perspectivas progressistas no Serviço Social brasileiro exigem, hoje, três desafios importantes e indissociáveis entre si:

1. a crítica radical ao capital e à sociedade que permite a sua perpetuação: o capitalismo;

2. a necessária explicação dos princípios que orientam essa direção social, bem como o debate com as expressões (neo)conservadoras que têm revisitado o Serviço Social;

3. os desafios atuais que se apresentam à profissão e o vínculo disto com a direção social empreendida.

Ousemos tecer alguns comentários nessa direção. 


\section{Sociedade do capital, reprodução do pauperismo e pensamento conservador}

A sociedade burguesa, ou seja, aquela organização societária que permite a acumulação contínua e ampliada do capital, o capitalismo, "aparece como uma 'imensa coleção de mercadorias' e a mercadoria individual como sua forma elementar." (MARX, 1983, p. 45 grifo nosso). A maneira como imediatamente a ordem do capital se apresenta é, como nos alertou Marx (1983), apenas sua aparição inicial, já que o capital é relação social, embora apareça como relação entre coisas, entre objetos. Todavia, como componente da totalidade social, as formas imediato-fenomênicas não são desnecessárias, descartáveis, mas absolutamente insuprimíveis como ponto de partida que permite deslumbrar a sua trama interna, o não imediatamente revelado (LUKÁCS, 1978; 2010; 2012).

Qualquer produto do trabalho humano se objetiva-exterioriza (se aliena) do produtor, adquire vida própria ao materializar-se. O produto na forma mercadoria, isto é, aquele produzido sob o mando do capital, não apenas se aliena (se exterioriza), mas - e ao mesmo tempo - se estranha em relação a seu produtor, não pertence aos trabalhadores que o produziram. Estes, ao entregarem a produção a quem comprou a sua força de trabalho, por meio de uma relação contratual assalariada, os donos dos meios de produção e do capital, têm suas energias criativas drenadas por um processo que produz mercadorias. Portanto, submete o valor de uso ao valor de troca, realiza o primeiro somente por meio do segundo, viabiliza carências e necessidades por meio da troca mediada pelo equivalente geral: o dinheiro (a única mercadoria que não se compra ou se vende - MARX, 1983, p 53-70).

Mais do que isso, o salário (o valor que se paga pela compra da força de trabalho com o próprio trabalho realizado pelo trabalhador) não corresponde ao valor do trabalho de fato realizado, mas ao valor médio para que a força de trabalho se reproduza como tal. Tal processo, portanto, gera um excedente que é apropriado pelos donos dos meios de produção, a mais-valia, seja pela simples extensão das horas trabalhadas (mais-valia absoluta) ou pela permanente inserção de tecnologias que intensifica o trabalho (mais-valia relativa) sem, necessariamente, aumentar as horas trabaIhadas. Ao fazer isso, o trabalhador-produtor se aliena-estranha por inteiro, em suas relações sociais, entrega seu trabalho como força humanizadora, criativa e útil, potencializadora de valores de uso, a um processo produtivo geral comandado pelo capital como produção universal de mercadorias (MARX, 1983, p. 154). Capital que "é trabalho morto, que apenas se reanima, à maneira dos vampiros, chupando trabalho vivo e que vive tanto mais trabalho vivo chupa." (MARX, 1983, p. 189 grifo nosso).

Essas características sustentam a análise crítico-dialética que Marx (1983) elabora acerca da economia política burguesa nas condições objetivas da segunda metade do século XIX, necessariamente fundada em um co- 
nhecimento guiado pela razão ontológica. Ou seja, por uma perspectiva que produz conhecimentos a partir da unidade-diversa entre duas dimensões bem definidas, diferentes, mas articuladas entre si: a dimensão gnosiológica, isto é, da razão intencionalmente orientada a conhecer o desconhecido materialmente posto; e a dimensão ontológica, ou seja, aquela que diz respeito à dimensão material da vida humana-social, vinculada à produção e reprodução de seres sociais reais (LUKÁCS, 2012). Esse processo de reconstrução de complexos sociais reais é tecido sob o ponto de vista da categoria da totalidade em que a singularidade é seu componente inicial, aparente, incapaz de revelar a trama que o compõe. Todavia, o singular é rico em determinações (nunca imediatamente reveladas), parte da totalidade social, expressão de processos universais que se objetivam nas realidades com particularidades ricas em mediações, em conexões reais-intelectivas que revelam sua trama interna mediata. Todo esse processo, composto pela dialética da singularidade, da universalidade e da particularidade (inteligíveis e inseparáveis entre si), compõe a totalidade como categoria necessária para a explicação do real e de seu movimento material (próprio e real - independentemente das mentes humanas pensantes). Destaca Lukács (2012, p. 243; 297), ao apontar os limites do idealismo objetivo de Hegel:

[...] É necessária, porém, a máxima clareza quanto ao fato de que o verdadeiro ponto de partida é a própria realidade, que sua decomposição abstrata conduz a categorias de espelhamento, cuja construção sintética representa um caminho para conhecer a realidade, mas não o caminho da própria realidade, embora seja óbvio que as categorias e conexões que surgem nesse processo possuem - enquanto reproduções ideais da realidade - caráter ontológico e não lógico. [...] a totalidade não é, nesse caso, um fato formal do pensamento, mas constitui a reprodução mental do realmente existente; as categorias não são elementos de uma arquitetura hierárquica e sistemática, mas, ao contrário, são na realidade 'formas de ser, determinações de existência', elementos estruturais de complexos relativamente totais, reais, dinâmicos, cujas inter-relações dinâmicas dão lugar a complexos cada vez mais abrangentes, em sentido tanto extensivo quanto intensivo.

É nesse sentido que, por exemplo, o sapato exposto na vitrine do templo que cultua o deus mercadoria, o shopping, aparentemente encerra, elimina, faz desaparecer todo processo que o explica como mercadoria. Sendo assim, o processo produtivo da forma final sapato, composto por trabalho humano-abstrato, comprado como qualquer mercadoria e pago por meio de um salário é, por essência, expressão de trabalho realizado e não pago (expropriado)². Ao fazer isso, toma o imediato como mediato, a

\footnotetext{
${ }^{2}$ Vale destacar que o enunciado pós-moderno, que afirma o fim do trabalho na sociedade dita "pós-industrial", desconsidera que a crise em curso não é do trabalho concreto e útil, mas da sua forma abstrata, alienada-estranhada. Isso, ademais, em hipótese alguma, significa o seu fim. Expressa, na verdade, as profundas e irreconciliáveis tensões e crises estruturais do capital.
} 
mercadoria sapato por si mesma, em si mesma, ocultando o processo responsável pela sua criação: o trabalho humano expropriado e suas relações (burguesas). Elimina, com isso, não apenas o processo que explica a produção daquele sapato ou de outros sapatos, mas de todas as mercadorias (guardadas suas particularidades), já que o processo de acumulação do capital é social, funciona como produção geral e ampla de mercadorias, interferindo nas relações sociais gerais, estabelecendo seu ritmo, suas regras, seus princípios.

Estão postas, aqui, as bases por onde o fetiche da mercadoria se desenvolve e se consolida em diferentes estágios do capitalismo. A sociedade do capital, então, acumula riqueza ao mesmo tempo em que amplia o pauperismo (absoluto ou relativo), que se traduz na chamada "questão social" ${ }^{3}$. Esta é entendida como situações de extrema pobreza que podem ser gerenciadas e administradas por meio de ações compensatórias e de uma "correção moral" que apela para a compreensão das classes mais abastadas e para a dedicação dos assalariados ao trabalho.

São conhecidas as reações conservadoras ao que se convencionou denominar como modernidade, ou seja, o período mais claramente inaugurado a partir da Revolução Gloriosa Inglesa (1688) e, sobretudo, como expressão mundial, a partir da Revolução Francesa (1789). A nova forma de produzir e reproduzir a vida humana, cujos germes se encontram no advento do Renascimento (século XV), o estabelecimento de novas relações sociais, gerou reações diversas contra seus princípios mais centrais. Esta reação conservadora, que durou pelo menos mais intensamente até o final do século XVIII, concentrou-se na crítica aos principais traços da revolução burguesa clássica: o racionalismo, a autonomia individual, o humanismo burguês, a dessacralização do mundo e a toda perspectiva que substituía o teocentrismo pelo antropocentrismo.

Edmund Burke (2012), em Reflexões sobre a revolução na França, tratou de defender - no século XVIII - o antigo regime e sua base social: o clero e a nobreza fundiária. Com uma forte perspectiva anticapitalista romântica, tece duras críticas à desagregação das instituições mais tradicionais, tais como a família como base moral, a igreja como orientadora espiritual e a autonomia dos indivíduos, todas elas formas gestadas para destruir a unidade social e a autoridade exercida por meio da tradição (ESCORSIM, 2011). Também são conhecidas, entre a segunda metade do século XVIII e as duas primeiras décadas do século XIX, as observações do Conde JosephMarie de Maistre: posições claramente contrárias à modernidade e às concepções mais democráticas presentes no pensamento de Rousseau, a partir de um absoluto desprezo pelo povo.

\footnotetext{
${ }^{3}$ Expressão nada afeita à tradição marxiana e marxista, utilizada pelo pensamento conservador a partir da segunda metade do século XIX.
} 
Todavia, um importante transformismo é operado por dentro do pensamento conservador na primeira metade do século XIX. O que até então o identificava com uma orientação claramente restauradora do antigo regime e negadora do modo burguês de ser e pensar assume, nesse momento (especificamente entre 1830 e 1848), um caráter claramente antirrevolucionário no sentido de afirmar a sociedade do capital. Há, aqui, nítida tendência em associar o conservadorismo com a defesa da sociedade burguesa como ordem social hegemônica, eliminando perigos potenciais à sua manutenção. Augusto Comte $(2012 ;$ 1984) alertou, na primeira metade do século XIX, para a necessidade de eliminar os "preconceitos revolucionários", assumir um "positivismo positivo", livre de tensões negativas, como "religião da humanidade", voltando-se contra resquícios revolucionários do final do século XVIII. Tocqueville (2014; 2011; 2003), no mesmo período, insistirá em uma "democracia administrada" e Le Play (1941) presenciando claramente a eclosão do movimento operário em 1848, salientará, com um toque religioso, a importância da família (particularmente a gestão de seu orçamento) como instância capaz de apoiar o indivíduo. Uma expressão mais elaborada e sociológica dessa tradição se objetivará em Émile Durkheim $(2014 ; 2010)$ nas primeiras décadas do século XX, com uma clara e otimista articulação entre conservadorismo, sociedade do capital (sobretudo na sua fração industrial) e produção técnico-científica no campo da sociologia positivista. Não por acaso, o conservadorismo é assumido pelo autor de As regras do método sociológico, seja em relação a seu método de estudo, seja em relação às revoluções (para ele tão "impossíveis quanto os milagres"). Desenvolveu, então, inúmeros conceitos vinculados à solidariedade orgânica, à ação social, à integração, à disfunção social, às patologias sociais, às funções manifesta e latente, às reformas morais/sociais e, como não poderia ignorar, à divisão do trabalho, com um claro enfoque na solidariedade e nas diferenças individuais ${ }^{4}$.

Foram postos, aqui, os germes de uma ciência puramente instrumental e subserviente à sociedade do capital, que Lukács (apud NETTO, 1981b) caracterizaria, no século XX, como "decadência ideológica". Ou seja, a destruição da razão e da ciência ontológicas, o cultivo à razão miserável, imediata, a clara unidade entre positivismo e conservadorismo, a especialização/fragmentação como forma de substituir a categoria da totalidade (LUKÁCS, 2010; 2012; 2013). Trata-se, basicamente, de uma inflexão do pensamento conservador no sentido de substituir a tradicional perspectiva comprometida com a restauração da antiga ordem por uma concepção que se acomoda ética, política e cientificamente com a sociedade burguesa industrial. Marx, por sua vez, adotando caminho oposto, visualizou e combateu essa decadência anunciada no século XIX. Destaca o autor de $O$ ca-

\footnotetext{
${ }^{4}$ Guardadas as diferenças necessárias, autores como Karl Popper (1998; 2013), Talcott Parsons (2010a, 2010b) Robert King Merton (1970), Vilfredo Pareto (In RODRIGUES, 1984), Friedrich Von Hayek (2013), além de toda tradição sistêmica presente desde Bertalanffy (1980) e Capra (2004), por exemplo, retomam heterogeneamente tais temas.
} 


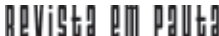

\} CRISE DO CAPITAL, NEOCONSERVADORISMO E SERVIÇO SOCIAL NO BRASIL - SILVA, J. F. S. \}

pital, ao comentar as posições do parlamento inglês em relação ao pauperismo e a ascensão do movimento operário:

De início, ele explica o terrível aumento do pauperismo como 'falha de administrativa' [...] O parlamento inglês não se restringiu à reforma formal da administração. Ele detectou a fonte principal da condição aguda do pauperismo inglês na própria Lei dos Pobres. O próprio meio legal contra a indigência social, a beneficência, favoreceria a indigência social. Quanto ao pauperismo em termos gerais, ele seria uma lei natural eterna, segundo a teoria de Malthus [...] O Parlamento inglês combinou essa teoria de caráter humanitário com o parecer de que pauperismo seria a miséria infligida a si mesmo pelo trabalhador, não devendo, em consequência, ser prevenido como um infortúnio, mas reprimido e punido com um crime. (MARX, 2010, p. $33-34)^{5}$.

Ora, a gênese do Serviço Social como profissão é impensável sem essa dinâmica. O final do século XIX, produto de tensões estruturais criadas e recriadas pela sociabilidade burguesa (SILVA; SANT'ANA; LOURENÇO, 2013), insolúveis sob suas fronteiras, apontaria para uma nova fase da sociedade do capital: o imperialismo (nos dizeres de Lenin 2008, p. 125-126) ou, em outras palavras, a era monopolista que nascia da fusão entre capital industrial e bancário ${ }^{6}$.

Inicialmente potencializado pelo padrão fordista de acumulação (responsável por oferecer as bases racionais para a organização da produção e da força de trabalho até meados da segunda metade do século XX), o capitalismo de monopólios intensificou a concentração de capitais ao mesmo tempo em que teve que responder às demandas sociais tensionadas pela luta de classes. Incrementando, paulatinamente, demandas situadas no campo dos direitos civis e políticos (o direito à liberdade nos padrões liberais e aos poucos convivendo com sufrágio universal regulado), a era monopólica lida com a "questão social" firmando determinados direitos trabalhistas, algumas redes de proteção social compensatórias, criando um amplo mercado consumidor e fábricas cuja força de trabalho era comandada pelo padrão fordista de acumulação. Faz isto, claro, apoiada em orientações bem diferentes da fase industrial (ainda que edificada sobre seu legado): a captura orgânica dos Estados Nacionais responsáveis por gerenciar-investir, com fundos públicos, os negócios da burguesia e administrar a "questão social"; a fusão de grandes grupos econômicos com o objetivo de reorganizar a produção e monopolizar mercados; a forte participação dos bancos, so-

\footnotetext{
${ }^{5}$ Também são certeiras as observações de Marx (1987, p. 80-81) sobre as escolas humanitária e filantrópica que atuaram com o pauperismo a partir da segunda metade do século XIX.

${ }^{6}$ Nota-se que os estudos clássicos de Serviço Social datam desse período (particularmente os de Mary Richmond, nos Estados Unidos), bem como são desta época as primeiras experiências de intervenção em nível de Serviço Social na Europa.
} 
bretudo por meio do crédito como forma de estimular a produção acelerada e em larga escala (típica dessa fase da acumulação).

Tal contexto necessitou de outra espécie de força de trabalho, não necessariamente vinculada à produção como trabalho produtivo, criador de mais-valia, com a participação direta do capitalista que compra o valor de uso da força de trabalho. Intensificam-se, então, formas improdutivas de trabalho, frequentemente vinculadas à esfera dos serviços, não diretamente geradores de mais-valia, mas essenciais para a gestão do mundo do capital, sua reprodução metabólica, na medida em que conta com profissionais que auxiliam a reprodução social (MARX, 1984, p. 105-106; 1985, p. 110; 115). Sendo assim, a força de trabalho é composta, simultaneamente, por trabalhadores produtivos, isto é, aqueles contratados diretamente pelo capital e criadores de mais-valia, e os improdutivos, ou seja, os que são empregados por agentes indiretos que auxiliam na reprodução geral, social do capital. Neles, produtivos ou não produtivos, se inserem os assistentes sociais (de acordo com sua posição na divisão social do trabalho) que devem lidar com as diversas expressões do pauperismo, como profissionais especializados, racionais e tecnicamente preparados para gerenciar tensões sociais. Sendo assim,

[...] na emergência profissional do Serviço Social, não é este que se constitui para criar um dado espaço na rede sócio-ocupacional, mas é a existência deste espaço que leva à constituição profissional [...] não é a continuidade evolutiva das protoformas ao Serviço Social que esclarece a sua profissionalização, e sim a ruptura com elas [...]. A profissionalização do Serviço Social não se relaciona decisivamente à 'evolução da ajuda', à 'racionalização da filantropia' nem à 'organização da caridade'; vincula-se à dinâmica da ordem monopólica. (NETTÓ, 1992, p. 69).

A ordem monopólica se desenvolveu ao longo do século XX desencadeando duas guerras mundiais (1914-1918 e 1939-1945 - expressão das divergências entre blocos de potências econômicas e disputa por mercados), tendo que lidar com crises cíclicas do capitalismo (particularmente a de 1930) e com a ascensão da União Soviética em 1917 (a primeira revolução proletária que persistiu por mais de 70 anos). O importante contraponto soviético não apenas ajudou decisivamente na derrota do nazifascismo como também impôs ao Ocidente capitalista a necessidade de oferecer um contraponto ao Oriente socialista: o Welfare State (Estado de Bem-Estar Social). Esse paradigma se sustentou em um pacto social firmado entre sindicatos e patrões, inspirado na tradição econômica keynesiana, certamente de base fordista, com economia aquecida, altos índices de empregos ("pleno emprego"), altas arrecadações gerenciadas pelo Estado burguês e a redistribuição relativa dos impostos também na forma de serviços e de direitos sociais. Isso certamente não eliminou a apropriação da riqueza 
socialmente produzida (a propriedade privada), mas abrandou, por um curto espaço de tempo, a desigualdade social em alguns países do continente europeu e, sobretudo, serviu para a reconstrução da Europa pós-II Grande Guerra Mundial.

Esse "lampejo humanitário" do capital, circunscrito a países europeus capitalistas desenvolvidos, durou pouco tempo. O ultraliberalismo (popularmente denominado "neoliberalismo") se intensificou com a crise do chamado "socialismo real"7 e a insustentabilidade dos padrões da economia keynesiana (ambos, claro, articulados como faces antagônicas de propostas societárias diferentes). Esta decadência gerada, antes de tudo, por uma profunda crise de acumulação do capital, claramente anunciada já na década de 1970, introduziu ideias ultraliberais e inaugurou os tempos "neoliberais" 8 .

Na América Latina esse processo não se reproduziu sem particularidades. Nela, a revolução burguesa se realizou mediada pelas determinações da era imperialista do capital, não como uma expressão imediata e direta das regiões economicamente centrais do globo, muito menos como um processo isolado, explicado pela dinâmica interna dos países latinos. Nações marcadas pelo desenvolvimento capitalista hipertardio e dependente produziram burguesias nacionais particulares cuja sobrevivência tem se sustentado na rendição ao imperialismo (do inglês, a partir do final do século XIX, ao norte-americano do pós-II Guerra Mundial), não assumindo, por sua natureza, um papel propriamente revolucionário, claramente empreendedor e dinamizador das forças produtivas no mundo do capital (como classe dominante propriamente dita). Não se submeteram, também por isso, ao controle das pressões democráticas nacionais (típicas das regiões mais centrais), amarrando seus interesses imediatos àqueles preconizados pelas regiões centrais.

Todavia, as classes sociais aqui constituídas não são diferentes das regiões economicamente mais privilegiadas do globo. O que particulariza a América Latina é a forma como o capitalismo se materializou, produziu e reproduziu, a partir de condições objetivamente dadas, como "força social" (FERNANDES, 2009, p. 47). O amadurecimento do imperialismo sob o comando norte-americano, desdobramento das duas grandes guerras mundiais, manterá esse padrão, aprimorando-o.

[...] Assim, enquanto o antigo imperialismo constituía uma manifestação de concorrência nacional entre economias capitalistas avançadas, o imperialismo moderno representa uma luta violenta pela sobrevivência e pela supremacia do capitalismo em si mesmo. [...]

\footnotetext{
${ }_{7}^{7}$ Vale destacar que todas as nações que fizeram parte do bloco liderado pela extinta União Soviética jamais foram comunistas (no sentido marxiano da palavra). Seguramente passaram por transições socialistas particulares que molestaram o capitalismo, mas não afetaram a acumulação ampliada do capital.

${ }^{8}$ Boas expressões dessas tendências apareceram nas obras de Friedrich Hayek (O caminho da servidão, publicado em 1944) e Milton Friedman (Capitalismo e liberdade, 1962).
} 
O novo padrão de imperialismo é, em si mesmo, destrutivo para o desenvolvimento dos países latino-americanos. A razão é facilmente compreensível. Não possuindo condições de crescimento autossustentado, para a integração nacional da economia e para uma rápida industrialização, os países capitalistas da América Latina estavam tentando explorar uma espécie de miniatura de modelo europeu de revolução burguesa, através de expedientes improvisados e oportunistas. (FERNANDES, 2009, p. 30).

A ordem monopólica impôs aos assistentes sociais, desde sua gênese como profissão, uma demanda objetiva, material e ontologicamente determinada, atrelada à gestão do pauperismo, como dado objetivo, insuprimível para essa profissão na ordem do capital. Ainda que tais determinações sejam gerais, como parte dos antecedentes do Serviço Social na era industrial e monopolista do capital, objetivam-se heterogeneamente com particularidades em diferentes regiões do globo, aspectos igualmente importantes (em nada desprezíveis) ${ }^{9}$. Ao mesmo tempo, essa determinação não impõe ao Serviço Social e aos assistentes sociais uma trajetória unicamente comprometida com as demandas do capital no campo da gestão de realidades afetadas por desigualdades estruturais (embora não possa descolar-se completamente delas, nas condições impostas por essa sociabilidade).

Ora, decodificar as expressões particulares do conservadorismo na profissão (suas expressões atuais) é procedimento essencial para lidar criticamente com esse "esterco de contradições" que se impõe não mecanicamente aos profissionais. Mais do que isso, é trajetória insubstituível para os que estão comprometidos com a construção de alternativas contra-hegemônicas, de resistência genuína, dentro e fora da profissão (respeitando suas limitações objetivas) ${ }^{10}$.

\section{3. (Neo)conservadorismo e Serviço Social no Brasil: notas para um debate crítico}

As condições objetivas para a gênese do Serviço Social como profissão, ou seja, "[...] como prática institucionalizada, socialmente legitimada e legalmente sancionada [...]" (NETTO, 1992, p. 13), foram postas, decisivamente, em escala mundial, pela dinâmica do capitalismo de monopólios, após as lutas operárias travadas na segunda metade do século

\footnotetext{
${ }^{9}$ O Serviço Social latino-americano, por exemplo, não deve ser explicado homogeneamente. Isso não invalida, por outro lado, a existência de determinações gerais e comuns vinculadas às estruturas do capitalismo monopolista de base fordista ou toyotista, mesmo que destaque particularidades nacionais, regionais e locais (diga-se de passagem, uma necessidade).

${ }^{10}$ Marilda lamamoto (2014, p. 213-612) destaca o avanço do (neo)conservadorismo na profissão e a necessidade de decodificá-lo com maior precisão (inclusive em sua forma mais tradicional - não suficientemente explorada), ao mesmo tempo que enfatiza a importância do legado crítico marxista no Serviço Social brasileiro e suas conquistas.
} 
$X I X$. A partir desse momento, as ações de cunho religioso e filantrópico (frequentemente, mas não unicamente, articuladas) adensam-se e imbricamse com as inciativas mais organizadas, mantidas pelos Estados Nacionais organicamente capturados pela dinâmica monopólica do capital e comprometidos com a "gestão responsável" do pauperismo. É nessa direção, ainda que de forma difusa e heterogênea, que atuam na gênese da profissão (com maior ou menor intensidade conforme o país considerado) tradições antimodernas (não apenas de perfil católico), com uma forte perspectiva anticapitalista romântica, defensora de valores e princípios devastados pela revolução burguesa consolidada, bem como tendências já oriundas de uma aproximação entre o pensamento conservador e a sociedade do capital do início do século XIX. Acomodam-se, aí, "valores humanitários", o manejo de abordagens científicas e a manutenção da ordem do capital, adensando e modernizando essa tendência ao longo de todo século XX. Nesse sentido, o pensamento conservador, ainda que diversamente mais avesso ou adequado às transformações desencadeadas pela Revolução Burguesa, foi componente estrutural da gênese do Serviço Social como profissão. Isso se expressou, por exemplo, nas Sociedades de Organização de Caridade (1869 e 1870 - nascidas na Inglaterra e nos Estados Unidos, respectivamente), espaços comprometidos em lidar com o pauperismo da época. Igualmente se inserem nesse contexto, já nas primeiras duas décadas do século XX, por caminhos diferentes, as experiências de atuação social franco-belga (de perfil católico-tradicional NETTO, 1981a; 1991) e a abordagem de caso sistematizada por Mary Richmond nos EUA (1917), afeita a certa sistematização científica (mesmo que com nítidos traços religiosos), como uma experiência mais clássica de Serviço Social ${ }^{11}$.

A gênese do Serviço Social no Brasil contou, originalmente, com uma base doutrinária no campo particular da secularização da Igreja Católica de tradição franco-belga, com forte influência das Encíclicas Rerum Novarum (1891) e Quadragésimo Anno (1931) ${ }^{12}$. Trata-se de elemento relevante no processo de sua constituição, ainda que não deva ser tomado como decisivo para situá-lo como profissão no Brasil. O Serviço Social brasileiro teve sua gênese inserida nessa trama tecida pela ordem monopólica do capital na sua fase fordista (em que se inserem o Estado, a Igreja e a denominada "questão social"), sem deixar de destacar que o desenvolvimento do capitalismo brasileiro se deu pela via colonial, hipertardia e dependente, com seus ranços centrados em uma economia focada na grande propriedade, no trabalho escravo e na produção agrícola. A revolução burguesa no Brasil (FERNANDES, 1987) teve seu impulso mais in-

\footnotetext{
${ }^{11}$ A evolução da vida familiar, o poder e a capacidade de coesão, a capacidade de afeto, a admiração, a formação adicional, o esforço para o desenvolvimento social, o conhecimento do marido e do pai dos filhos das mulheres, a individualização dos filhos no núcleo familiar, o orçamento familiar e os hábitos de alimentação e habitação são destacados por Richmond (em 1917) em seu livro Diagnóstico Social (2005).

${ }^{12}$ Os documentos de época do Centro de Estudos e Assistência Social (CEAS - 1932) e a fundação da primeira escola de Serviço Social no Brasil em São Paulo (1936) revelam isso claramente.
} 
tenso a partir do projeto urbano-industrial desencadeado no primeiro governo nacional-desenvolvimentista de Getúlio Vargas (1930-1945), o que demonstrou, com requintes particulares, a forte presença do Estado no adensamento do capitalismo e da economia de mercado no Brasil ${ }^{13}$.

A base doutrinária do Serviço Social tradicional persistiu com forte e clara presença por muitos anos (e, em certo sentido, sob outras determinações, ainda se faz muito presente). Ela contaminou a formação profissional e a institucionalização da profissão nas décadas de 1940 e 1950 (IAMAMOTO; CARVALHO, 1985), adentrando nos anos 1960, que marcariam sua decadência (mas não extinção) após a renovação do Serviço Social durante o movimento de reconceituação latino-americano. A renovação do Serviço Social brasileiro, situada entre a segunda metade dos anos 1960 e primeira metade dos anos 1970 (portanto, objetivada em plena autocracia burguesa e sua ditadura no Brasil, a partir de 1964 - NETTO, 1991; 2014), reeditou o conservadorismo profissional. Fez isto eclética e heterogeneamente (a partir da base sincrética ontologicamente dada à profissão) reproduzindo duas tendências dominantes ${ }^{14}$ : a) a primeira, inspirada em uma tradição positivista-funcionalista ajustada às condições operativas do Serviço Social, claramente cientificista, atualizando a metodologia de caso, grupo e comunidade dos anos 1950, com forte ênfase no desenvolvimento com integração social, absoluta subserviência à ordem em curso e clara reedição de ações que visavam reparar (não apenas moralmente) indivíduos, grupos e comunidades, como preconizadas nos documentos de Araxá e de Teresópolis (ocorridos, respectivamente, em 1967 e 1970,); b) a segunda reavivou e modernizou a abordagem individual, com ênfase na "pessoa humana" de orientação neotomista, de inspiração fenomenológicapersonalista, também cientificista, eclética, justapondo autores como Husserl, Heiddeger, Mounier, Merleau Ponty, entre outros, e propondo uma abordagem centrada na dinâmica articulada no eixo diálogo, pessoa e transformação social, conforme explicitado nos estudos amplamente conhecidos de Anna Augusta de Almeida e de seu grupo ${ }^{15}$.

A possibilidade de uma interlocução diferenciada e fecunda expressou-se (não sem problemas) nos estudos de Leila Lima dos Santos (denominado $O$ Método $B H$ ), inauguradora do que Netto (1991) denominou

\footnotetext{
${ }^{13} \mathrm{Na}$ América Latina, o nacional-desenvolvimentismo focou sua atenção, estrategicamente, em um crescimento econômico que visava alterar a estrutura produtiva (substituição de importações) e reduzir as vulnerabilidades externas (alteração do padrão de comércio exterior, encurtamento do hiato tecnológico e tratamento diferenciado para o capital estrangeiro GONÇALVES, 2012, p. 652).

${ }^{14}$ A tese apresentada por José Paulo Netto $(1991 ; 1992)$ sobre o sincretismo no Serviço Social (ainda que se discuta se ele deve ser entendido como diferenciado ou indiferenciado - como aponta IAMAMOTO, 2007) possui, segundo nossa opinião, grande concretude ontológica e universalizante (não vale apenas para o Serviço Social no Brasil). A mesma consideração pode ser feita sobre as pertinentes observações sobre a gênese da profissão na era de monopólios e sobre a profissão inserida na divisão social e técnica do trabalho como especialização do trabalho coletivo (IAMAMOTO; CARVALHO, 1985).

${ }^{15}$ Não nos cabe, aqui, avançar nessa discussão fartamente explorada. Para uma incursão crítica é indispensável a leitura de Netto (1992) e, obviamente, dos próprios textos originais.
} 
como "intenção e ruptura". Esta perspectiva critica as abordagens tradicionais e modernas no âmbito do Serviço Social, o modelo de desenvolvimento adotado pela autocracia burguesa no Brasil e na América Latina, salientando a necessidade de os profissionais "organizarem" e "capacitarem" as camadas expropriadas (ainda que reproduza, com isso, um inegável messianismo e uma forte preocupação cientificista estranha a Marx e à sua dialética).

Cabe destacar, então, que os segmentos profissionais dentro e fora das universidades, mais ou menos próximos às lutas sociais travadas nas décadas de 1980 e 1990, foram vinculados ou, pelo menos, influenciados por essa tradição de inspiração marxista no Serviço Social. No caso brasileiro, isso se deu por meio de uma forte aproximação com as lutas empreendidas pelos movimentos sociais a partir do final dos anos 1970. Passou por uma aproximação com a esquerda católica (particularmente a Teologia da Libertação - e aqui a presença doutrinária se fez por outras vias) e também se enriqueceu, gradualmente, com o adensamento do debate com Marx e sua tradição. Adensou-se nos anos 1980 e, decisivamente, nos anos 1990, com a construção de uma hegemonia profissional claramente progressista, defensora de direitos, democrática, com consequências práticas importantes para a profissão no Brasil: revisão e amadurecimento de um novo Código de Ética, viabilização de uma proposta curricular nacional e crítica (ainda que parcialmente descaracterizada pelas instâncias governamentais da época), consolidação de uma direção social estratégica (como projeto profissional hegemônico) conhecida como Projeto Etico-Político Profissional, além de atuar em inúmeras lutas sociais que se desdobraram em importantes conquistas democráticas no Brasil.

Todavia, a era de monopólios inspirada no padrão toyotista de acumulação, que reafirma e radicaliza a tendência desencadeada no final do século XIX, sob o comando do capital financeiro, impactou a América Latina nos anos 1990 (sobretudo em sua segunda metade). Houve uma intensa alteração naquilo que Marx (1984, p. 195-196) caracterizou como composição orgânica do capital, ou seja, uma brutal diminuição dos investimentos em capital variável (destinados à compra da força de trabalho) e o crescimento/manutenção dos investimentos em capital constante (sobretudo na inserção de tecnologias de ponta). Isso vem acelerando a substituição de trabalho vivo por trabalho morto ${ }^{16}$, intensificando a produção, sem necessariamente contratar força de trabalho adicional (aliás, uma estratégia utilizada pelo capital em outras fases da acumulação). Faz isto desmobilizando os sindicatos de trabalhadores, fragmentando a luta daqueles que vivem da venda de sua força de trabalho, criando uma massa de desempregados permanentes e imprestáveis para o capital, isto é, sem valor de uso/troca, ou possuidor de um valor marginal pago para preencher serviços precários e de menor qualificação profissional.

${ }^{16} \mathrm{O}$ que não significa a eliminação da força de trabalho viva, mas sua brutal diminuição e precarização. 
Reorganiza-se, então, o mercado de trabalho mantendo parte dos trabalhadores formalmente empregados e uma parcela imensa e heterogênea de precarizados, subcontratados, informais, parciais, terceiros, ambulantes, diaristas, entre outras modalidades (ANTUNES, 1999; 2000). Intensifica-se o trabalho estranhado cortando custos de produção, flexibilizando direitos trabalhistas sob o argumento de tornar o deus mercadoria competitivo em seu valor de troca e, cinicamente, com isso, "manter e criar mais empregos". Tudo isso com a anuência do Estado burguês e de seus governos "democráticos" que sistematicamente transferem fundos públicos para "manter empregos", criar infraestrutura para a sua produção e seu adequado escoamento, manter o "mercado aquecido" subsidiando negócios privados (BEHRING, 2012) ${ }^{17}$.

Tais dificuldades, ontologicamente dadas, obviamente não exclusivas à categoria profissional dos assistentes sociais, particularizam-se nela intensificando e gerando questões objetivas e concretas para o trabaIhador assistente social: intensificação do trabalho, redução de direitos, subcontratações, dificuldades para a requalificação profissional, entre outras questões mais diretamente afeitas ao profissional propriamente dito. Ao mesmo tempo, foram seriamente afetadas as condições materiais do trabalho profissional, processo este não necessariamente marcado pela redução de recursos investidos, mas pela forma como devem ser gerenciados em nome da "participação cidadã" e da "defesa da democracia", no sentido de reduzir a pobreza extrema, como assistência social despida de seguridade social, ainda que crítica ao assistencialismo.

Ora, terreno fértil, claro, para a reedição do velho como "velhonovo", comprometido unicamente com o "miúdo" e "sua verdade", com a gestão da assistência social (em si mesma). O processo ideológico se completa: a assistência social, que se objetivou como conquista de um longo processo de lutas por níveis crescentes de emancipação social (inclusive com ampla participação dos assistentes sociais), é tomada em si como meta a ser cumprida e priorizada, ainda que efetivamente descolada do campo da seguridade social e, portanto, da universalização de direitos (embora idealisticamente o que se pretenda, na maioria das vezes, seja o contrário).

O conservadorismo, então, moderniza-se também no âmbito do Serviço Social, realimenta as velhas teses, travestindo-as de novas, de atuais, de mais realistas, mais próximas e "concretas" para "prática profissional" dos assistentes sociais. Faz isto, claro, renovando-se, reatualizando-se, sem alterar sua estrutura interna. São reeditadas, então, na era da pósmodernidade e da chamada "crise dos paradigmas" nas Ciências Humanas e Sociais (certamente úteis no atual estágio de acumulação do capital), ve-

\footnotetext{
${ }_{17}$ Negociatas? O patrimonialismo burguês-tardio critica incentivos fiscais destinados "ao outro", "ao diferente" e, sobretudo, aos "gastos" sociais "estimuladores da preguiça". Por outro lado, considera tais incentivos como "investimentos" necessários, "criador de empregos" (?). "Venha a nós o vosso Reino"!
} 
Ihas receitas comprometidas com velhos conceitos requentados e com "novas e certeiras soluções". Isso, no campo particular do Serviço Social, tem se expressado em diversas tendências teórico-metodológicas em curso (claramente ou não), retomando e reacomodando, simultaneamente, traços novos com o passado profissional (NETTO, 1996). Tais tendências têm se manifestado ora de forma mais organizada, ora de maneira mais dispersa e isolada, seja no campo da produção do conhecimento, seja no âmbito mais diretamente vinculado à gestão social e ao trabalho profissional (IAMAMOTO, 2007). No geral, reproduzem, não homogênea, mas complexamente, os seguintes aspectos:

a) resistência e/ou dificuldade em estabelecer os limites estruturais da ordem em curso, suas contradições, bem como fragilidades, para explicitar as particularidades do Serviço Social como profissão inserida nessa ordem societária. Nesse âmbito, duas dimensões se destacam: a reedição de análises absolutamente despidas de economia política (amplamente caracterizadas como "sistêmicas") e, também por isso, uma visão, pelo menos implícita, de que é possível reformar a ordem em curso (humanizá-la). As consequências aqui são inevitáveis: desinteresse e/ou fragilidade para estabelecer mediações entre as determinações estruturais e as demandas imediatamente postas à profissão. $\mathrm{O}$ "miúdo", então, passa a falar por si mesmo, na sua imediaticidade;

b) subalternização ou menor importância da teoria, do estudo e da pesquisa como parte constituinte e fundamental do trabalho e da formação profissionais. Ao contrário do que se pensa, essa diminuição não ocorre apenas em diferentes formas de praticismo (mais ou menos messiânicos) mas, e principalmente, por meio de tendências que também valorizam certo tipo de teoria, ou seja, de conhecimentos teóricos que respondem mais imediatamente à prática como "conhecimento necessário". Reeditamse, aqui, formas de pragmatismo e de utilitarismo no campo da produção e apropriação de conhecimentos;

c) a valorização da teoria, do estudo e da pesquisa, mas sustentados na ciência abstrata, estranha à realidade (por isso antiontológica), na especulação teórica que apanha e reorganiza um leque de conhecimentos heterogêneos capazes ou não de responder às demandas profissionais. Trata-se de uma reedição da ciência abstrata, que atribui ao intelectual o papel de organizar os conhecimentos, para "os da prática", na divisão social do trabaIho. O Serviço Social, então, deve ter seus "intelectuais" "pouco comportados intelectualmente" (mas adequados política e praticamente), ecléticos, negadores e críticos dos paradigmas (como utilitaristas pós-modernos conscientes e letrados), defensores da verdade miúda e imediata, mentes pensantes e objetivas, cultas, reprodutoras de posições políticas avessas à economia política e resignadas com a ordem do capital (na esteira weberiana da crítica resignada $\mathrm{COHN}, 2003)$; 
d) a retomada da discussão do pluralismo profissional como justaposição harmônica dos diferentes, na perspectiva da "verdade relativa", vinculada ao ponto de vista de cada um e ao "respeito" aos diferentes sem, todavia, empreender o debate crítico necessário. Frequentemente, nesse caso, a tentativa de um debate mais intenso e radical é visto como "desrespeito à pessoa humana" na esteira da tradição neotomista. Há, pois, a reedição de um velho princípio: a explicação da profissão a partir de sua dinâmica interna, de seus referenciais, ao mesmo tempo em que se reeditam formas de departamentalização do "social" e da própria profissão;

e) a consequência final não poderia ser outra: desinteresse e/ou dificuldade para visualizar a relação dialética como unidade diversa, entre a profissão Serviço Social e níveis crescentes de emancipação social, para além da ordem do capital. Aqui, o processo é duplamente complexo: por um lado, ele sofre o impacto dos grupos refratários a qualquer procedimento que possa sintonizar, não mecanicamente, os projetos profissionais com projetos societários mais amplos, sobretudo aqueles cujas lentes miram "para além do capital"; por outro lado, é desconsiderado por setores que acreditam que as profissões nada podem contribuir com níveis crescentes de emancipação social como espaço contraditório útil ao acúmulo de forças. Disto deriva outro problema: a absoluta incapacidade de pensar concretamente os limites profissionais, suas potencialidades, reproduzindo imobilismos ou messianismos (IAMAMOTO, 1994) que atribuem tudo ou nada ao espaço profissional (nesse caso, por diferentes espectros teóricos).

Não se trata, aqui, em absoluto, de impor um enquadramento às pessoas ou grupos que reproduzem suas convicções dentro e fora do Serviço Social (mesmo porque se trata de um processo difuso, complexo e nada homogêneo), mas de reconstruir tendências reais em curso que, por diferentes caminhos, reeditam traços de uma perspectiva não ontológica, cientificista, no campo particular do Serviço Social. Essa decodificação é importante para esclarecer os traços (neo)conservadores presentes nas tendências teórico-práticas e ético-políticas em curso na profissão, adensando seu debate (BARROCO, 2011).

Para aqueles que se sentem confortáveis em gerenciar o caos, o incômodo aparece como uma "nova questão social", um "novo desarranjo" que exige um "novo conhecimento" e uma "nova forma de gestão" (a velha estratégia é reeditada sob outras condições e contradições). Essa perspectiva, com suas variações, fiel depositária do legado modernizador de parte do Serviço Social renovado (NETTO, 1991, p. 164), baseia-se na absoluta subserviência da profissão e dos profissionais à ordem em curso. O foco central está na integração empreendedora e solidária dos "usuários", centrada no empoderamento do indivíduo visando à sua integração sistêmica, reproduzindo um discurso ideológico que relativiza os direitos e ignora qualquer tipo de crítica à economia-política burguesa, reiterando-a por completo. 
O profissional de Serviço Social deve ser um "técnico social" bem adestrado, competente e criativo na gestão da política oficial, circunscrito às fronteiras institucionais, a seus limites. A formação universitária se reduz ao essencialmente necessário à viabilização das regras institucionais, nisto a competência do profissional, reproduzindo, no geral, tendências teóricas heterogêneas e ecléticas comprometidas com as reformas sociais "bem comportadas", necessárias à saúde social e "solidárias" (leiase, esvaziadas de qualquer perspectiva de classe).

Os conteúdos de economia, de política, de história e de filosofia são pontualmente recuperados, reforçando uma economia "econômica" e economicista (desprovida totalmente de economia-política), uma política "dita a-política" (no seu limite "responsável"), uma "história" a-histórica, desvinculada dos problemas humanos concretos, e uma filosofia "enciclopédica" (especulativa). Em contraposição, sugere-se uma "ciência" não ontológica, sustentada em procedimentos "qualitativos" e quantitativos responsáveis pelo tratamento equilibrado, "científico", que impõe uma lógica estranha, externa à própria realidade. Tudo isto submetido às demandas imediatamente postas à profissão no campo da "prática profissional", que não suporta reflexões críticas "desnecessárias", "abstratas" e "distantes da realidade" enfrentadas pelos profissionais de Serviço Social. Trata-se, no limite, sob essa ótica, de um problema de gestão política que carece de bons gestores da política em curso. O compromisso Ético-Político Profissional dos assistentes sociais se reduz à realização "do possível a ser feito" (quando muito), por doses homeopáticas que se somam gradualmente na construção harmônica e respeitosa de uma "sociedade mais justa", sem desobediência civil às regras "democráticas", em defesa daquilo que "de fato a profissão faz", da sua "prática", daquilo que é imediatamente demandado por ela e por seus usuários.

Há, todavia, uma segunda tendência no Serviço Social contemporâneo que concentra o foco da profissão no campo da emancipação política (MARX, 2009, p. 70-71), da afirmação e da defesa de direitos (ora existentes). Centra-se, por isso, na participação política como a forma principal para viabilizar gradualmente direitos e, a partir disto, contribuir para a construção de "outra sociedade". A ordem burguesa deve ser reajustada, reformada, reorganizada e aperfeiçoada (leia-se, humanizada) por meio das instâncias participativas (conselhos, comissões, atividades de bairro territorialmente definidas e outros espaços), sendo que os assistentes sociais atuam no sentido de reduzir desigualdades, viabilizar programas e projetos sociais capazes de potencializar a "inclusão participativa" dos "usuários excluídos" nos serviços disponíveis e nas ações sociais oficiais atualmente centrados na gestão da pobreza absoluta (dos mais pobres).

Identificando emancipação política com emancipação humana, ou pelo menos vinculando a segunda como desdobramento gradual da primeira, essa tendência prioriza uma formação profissional humanista no 
sentido de preparar os profissionais para que gerenciem e viabilizem direitos, tendo a legislação social em curso e marcos teóricos centrados na análise das políticas setoriais/sociais como a referência principal. A pesquisa e a produção de conhecimentos são valorizadas (para além do simples tecnicismo da primeira tendência), desde que atentas à sistematização e/ou análise de assuntos vinculados mais diretamente às demandas socialmente postas ao Serviço Social. Neste contexto, temas como o binômio "exclusãoinclusão", vulnerabilidades, território, mínimos sociais, conselhos de direitos, capacitação continuada, trabalho socioeducativo, gestão-gerenciamento, redução das desigualdades, direitos específicos de grupos sociais (mulheres, idosos, crianças-adolescentes, homossexuais, portadores de diferentes deficiências físicas ou mentais, entre outros), adquirem visibilidade nas suas especificidades (na sua "face única"). Há, todavia, um tratamento da política destacada da crítica à economia-política, ou pelo menos sem referência enfática a ela, bem como uma recorrência diversa (frequentemente eclética) no marco teórico que ilumina a reflexão e a ação no campo do trabalho profissional.

A terceira tendência, fiel depositária do legado de "intenção de ruptura" (NETTO, 1991, p. 247), sustenta-se na crítica ao mundo do capital e a seus mecanismos de produção e reprodução ampliada. Ainda que, evidentemente, não caiba à profissão enfrentar/solucionar questões de ordem estrutural que se situam para além de suas fronteiras (uma tarefa da práxis revolucionária), a crítica radical à apropriação privada da produção social permite uma explicação das bases ontológicas, materiais, que agiram desde a gênese do Serviço Social como profissão e que explicam sua inserção na divisão social do trabalho, como parte da produção mundial-social, sua crescente complexização a partir da era monopólica-imperialista do capital e suas particularidades nas sociedades que realizaram sua revolução burguesa pela via colonial e hipertardia (nisto, a questão social - sem aspas produzida e reproduzida a partir da "lei geral da acumulação capitalista").

Não cabe, para esta tendência, confundir profissão, partidos e movimentos sociais (instâncias diferentes, mas relacionadas entre si), bem como é preciso articular as dimensões teórico-metodológicas, ético-políticas e técnico-instrumentais na práxis profissional como relação entre teoria e prática que não identifica nem submete uma esfera à outra, não adota uma perspectiva de "aplicação teórica", de um receituário teórico ou de uma "prática" que recorta da teoria o que interessa imediatamente. A teoria é consequência de um processo em que a razão reconstrói, como "concreto pensado" (MARX, 1989, p. 410), a dinâmica materialmente dada, suas condições e determinações reais (como expressão mental do movimento real), analisando criticamente tais determinações, nas suas múltiplas mediações, devolvendo-as como ações efetivas capazes de interferir na vida real, sem anular ou superestimar o papel dos sujeitos históricos e das condições reais existentes. Há, neste sentido, uma clara distinção entre eman- 
cipação política e emancipação humana (MARX, 2009, p. 71), não para desqualificar a primeira em relação à segunda, mas para defender a primeira a partir do horizonte da segunda, não como pura defesa da política em si, dos direitos políticos (gradualmente), mas como práxis saturada de crítica à economia-política.

O profissional de Serviço Social, então, não nega o espaço institucional, mas tensiona suas contradições, revela seus limites, investe suas forças genuinamente humanas no que imediatamente não aparece como prioritário, valoriza uma formação profissional que forme intelectuais no sentido de pensar criticamente e agir propositivamente (generalistas que não abrem mão de uma formação ampla sustentada em conteúdos de História e de Filosofia concretas). Desta forma, a apropriação crítica da teoria é plural mas não é eclética, priva pelo debate entre os diferentes (como passo necessário à crítica radical), mas não aceita a justaposição deles como meio pragmático e utilitarista (como um atalho) para a explicação do real e para a atuação profissional. O desafio, aqui, está em clarear as diferenças objetivas entre profissão (seus limites e potencialidades concretas) e as organizações político-partidárias e movimentos sociais libertários, comprometidos com uma crítica mais direta à sociedade do capital. Mais do que isso, é preciso unificar tais dimensões sem identificá-las, sem exigir das profissões o que elas não podem realizar.

Resumidamente, para os que se identificam com o que se convencionou denominar Projeto Ético-Político Profissional, edificado ao longo dos anos 1980 e 1990, cabe uma dupla tarefa contraditória nos dias atuais: afirmar e defender direitos em uma sociedade que os restringe continuadamente, tendo a clareza de que essa empreitada não realizará as tarefas grandiosas de superação da ordem do capital (e esse é um aspecto importante, embora pareça óbvio imediatamente). A defesa de direitos hoje se identifica, necessariamente, com uma orientação anticapitalista, e esse debate crítico deve ser também travado com as ilusões neodesenvolvimentistas em curso na América-Latina ${ }^{18}$.

[...] O verdadeiro resgate da tradição crítica do pensamento latinoamericano passa pela superação de toda ilusão em relação à existência de uma solução burguesa para a tragédia do subdesenvolvimento e da dependência. O caminho da crítica encontra-se no polo oposto da perspectiva provinciana, das opções de classe e das escolhas teóricas neodesenvolvimentistas. (SAMPAIO JÚNIOR, 2012, p. 686).

Ao mesmo tempo, cabe ressaltar que a profissão não cumprirá tarefas que não cabem a ela (vinculadas à transposição revolucionária e ao

\footnotetext{
${ }^{18} \mathrm{O}$ novo desenvolvimentismo se distingue do nacional-desenvolvimentismo pois se aproxima com o Consenso e o Pós-Consenso de Washington, incorporando traços da concepção liberal de desenvolvimento. Converge na estabilidade macroeconômica e no crescimento dinamizado por meio das exportações, ainda que critique a tríade maldita: superávit primário, juros altos e câmbio flutuante (CASTELO, 2012, p. 639; 664).
} 
início de uma transição socialista), tarefa dos movimentos sociais, dos sindicatos, dos trabalhadores (na sua diversidade) e dos partidos políticos libertários. Entretanto, a profissão e os profissionais devem acumular forças e enriquecer sua base teórico-prática, seus conhecimentos sobre os confins da sociabilidade burguesa, suas mazelas insolúveis, suas "patologias incuráveis". Esse acúmulo estimulado pela razão ontológica (SILVA, 2013a; 2013b), pelo pensar-fazer, pela crítica-crítica da política em curso (exercitando o sentido negativo da política), pela unidade-diversa entre a teoria e a prática, pela práxis (também profissional), muda substancialmente a nossa inserção como assistentes sociais nos espaços das instituições burguesas e dinamiza a possibilidade histórica de uma contracorrente no Serviço Social.

\section{Apontamentos inconclusivos: o legado crítico do Serviço Social brasileiro posto à prova}

São diversos e intensos os desafios para afirmar a direção social aqui esboçada e discutida (sem qualquer espécie de romantismo). Esse contexto é marcado, intrinsecamente, por um cenário altamente contraditório, que põe o Serviço Social em contradição com elementos que estão contidos na sua gênese e o justificam como profissão na sociedade do capital. A resistência aqui destacada deve ter a clareza de que o Projeto Ético-Político Profissional, como direção social, tão somente tem sua finalidade como tal, ou seja, como referência geral.

Vinculado a projetos sociais mais amplos, situados muito além do campo restrito das profissões, os valores contidos nesse projeto e no próprio Código de Ética Profissional (a defesa da liberdade, da equidade, da justiça social, de níveis crescentes de emancipação social - no sentido amplo e mais profundo dessas terminologias), somente poderão ser objetivados "para além do capital" (MÉSZÁROS, 2002; 2003). Isso não significa que a luta por dentro da ordem, a resistência inteligente e acumuladora de forças sociais genuinamente humanas, que tensione permanentemente as contradições insolúveis da ordem societária em curso, seja desnecessária. Ao contrário, as formas propositivas de resistência alimentam a criação de alternativas possíveis, objetivamente dadas e claramente orientadas, ainda que submetidas à mercantilização intensa das relações humanas e sociais.

No campo particular do Serviço Social, alguns velhos-novos temas merecem atenção. Deve-se ressaltar, prioritariamente, a necessidade de continuar estimulando estudos sobre o intenso processo de mercantilização e de privatização da educação brasileira, bem como ações do conjunto CFESS-CRESS, ABEPSS e ENESSO que resistam efetivamente a esse cenário (sobretudo em relação à formação profissional aligeirada - BRAZ; RODRIGUES, 2013). Qualquer possibilidade verdadeiramente democrática e 
comprometida com o cultivo da crítica radical e propositiva (como intelectuais que pensam e que fazem a partir de condições objetivamente dadas) carece da existência de espaços e de condições reais para tal.

Nessa mesma direção, Marilda lamamoto (2014, p. 634) chama a atenção para a necessidade de explicar mais apropriadamente as linhas teórico-metodológicas atualmente em curso, nisso a convivência críticorespeitosa entre elas e o sentido correto do pluralismo (na direção tratada nesse artigo). Destaca, ainda, a necessidade de impulsionar pesquisas que tratem do atual mercado de trabalho do assistente social no Brasil (nos seus diferentes espaços sócio-ocupacionais) que analisem a formação sócio-histórica da sociedade brasileira e latino-americana, estimulando um debate mais continental (algo importantíssimo).

Vale destacar, aqui, a necessidade de estimular pesquisas que descortinem os dois polos das classes sociais fundamentais apontadas por Marx (1983; 1984; 1985): os donos dos meios de produção, suas teses e argumentos e, por outro lado, temas mais diretamente pertinentes à realidade das camadas que vivem da venda da força de trabalho (considerando os inúmeros temas transversais que aqui se expressam: violência, gênero, raça, etnia, questões urbanas e rurais, entre outros). Tais construções devem adotar, necessariamente, o caminho da ciência ontológica e "não neutra" como reconstrução histórica, nunca exata e que extrai da realidade sua lógica, orientada pelo ponto de vista do trabalho, questionando o tratamento departamentalizado e focal do "miúdo", do território, do espaço imediatamente exposto aos olhos do assistente social e onde concretamente exerce seu trabalho.

O Projeto Ético-Político do Serviço Social aqui destacado, da forma como foi originalmente concebido, não possui qualquer vínculo comprocedimentos que tendem a identificar ou justapor tendências e grupos sociais antagônicos. O pluralismo nele contido não contempla qualquer chance nessa direção. O sentido é muito claro: esse projeto exige, de partida, como elemento básico, essencial, o compromisso firme (teórico-prático) com a defesa de direitos, sustentado em uma clara perspectiva anticapitalista capaz de orientar tal defesa. Não há, portanto, para os adeptos dessa direção social, a menor possibilidade de harmonizar o capital a perversidade de sua reprodução ampliada madura com a afirmação de direitos.

Fora desses parâmetros, as expressões do conservadorismo moderno, como manifestações (neo)conservadoras, tendem ao recrudescimento também no campo teórico-prático e ético-político do Serviço Social. De nossa parte, as melhores condições para a defesa propositiva de direitos surgem de inciativas inspiradas no legado deixado por Marx, por sua tradição, pela ênfase no ponto de vista do trabalho, pela crítica permanente e impenitente à apropriação da riqueza socialmente produzida (a propriedade privada) e pelo diálogo disso com a particularidade da profissão (e isso não é menos importante). Isto em hipótese alguma elimina o debate entre os 
diferentes (ao contrário), mas não os identifica como parte de um mesmo bloco construído em nome de uma unidade abstrata e incoerente com os objetivos propostos. Entendemos que a adoção desse ponto vista oferece as melhores condições para articular duas dimensões essências à ciência genuinamente ontológica: a não neutralidade científica (assumindo a defesa do trabalho concreto, útil e criativo) e o compromisso em produzir conhecimentos a partir da vida real daqueles que vivem da venda da força de trabalho. Construir ciência a partir destas condições não é uma tarefa fácil, embora isto seja urgente, crucial e genuinamente científico.

Isso não é um detalhe "teórico" restrito aos que insistem em "colocar defeitos" na profissão e nos profissionais, "desprezá-los", mas um exercício necessário à qualificação crítica tão cara à emancipação social de homens e de mulheres. Seguramente o Serviço Social e os assistentes sociais têm algo a contribuir com isto, ainda que se trate de uma grandiosa construção social e coletiva situado muito além do horizonte das profissões. Nisto, certamente, "A história de toda a sociedade até hoje é a história de lutas de classes" (MARX, In NETTO, 2012,185). Ou será que uma alternativa mais leve e "politicamente correta" deveria ser adotada na defesa do Projeto Ético-Político Profissional? 


\section{Referências}

ANTUNES, R. Adeus ao trabalho? Ensaios sobre as metamorfoses e a centralidade do mundo do trabalho. São Paulo: Cortez; Campinas: Ed. Unicamp. 1999.

. Os sentidos do trabalho. Ensaio sobre a afirmação e a negação do trabalho. São Paulo: Boitempo. 2000.

BARROCO, M. L. S. Barbárie e neoconservadorismo: os desafios do projeto ético-político. Revista Serviço Social e Sociedade [online], n. 106. 2011.

BEHRING, E. R. Rotação do capital e crise: fundamentos para compreender o fundo público e a política social. In: BEHRING, E. R.; GRANEMANN, S.; BOSCHETTI, I. (org.). Financeirização, fundo público e política social. São Paulo: Cortez Editora. 2012.

BERTALANFFY, L. Von. Teoría general de los sistemas. México: Fondo de Cultura Económica, 1980.

BRAZ, M.; RODRIGUES, M. O Ensino em Serviço Social da Era Neoliberal (1990-2010). In: SILVA, J. F. S. et al. (org.). Sociabilidade burguesa e Serviço Social. Rio de Janeiro: Lumen Juris. 2013.

BURKE, Edmund. Reflexões sobre a revolução na França. Rio de Janeiro: Topbooks, 2012. (Coleção Liberty Classics)

CHESNAIS, F. A mundialização do capital. São Paulo: Xamã. 1996.

CAPRA, F. O ponto de mutação - a ciência, a sociedade e a cultura emergente. São Paulo: Editora Cultrix, 2004.

CASTELO, R. O novo desenvolvimentismo e a decadência ideológica do pensamento. Revista Serviço Social e Sociedade. São Paulo: Cortez Editora, n. 112, out./dez. 2012.

COHN, G. Crítica e resignação. São Paulo: Martins Fontes. 2003.

COMTE, Augusto. Física social. Madrid: Akal Ediciones, 2012. (Colección Universitaria)

. O Espírito positivo. Lisboa: Res Editora, 1984.

Durkheim. E. As regras do método sociológico. São Paulo: Martins Editora, 2014. $\overline{2010 .}$

. Da divisão do trabalho social. São Paulo: WMF Martins Editora, ESCORSIM, L. O conservadorismo clássico. São Paulo: Cortez Editora. 2011. FERNANDES, F. A revolução burguesa no Brasil: ensaio de interpretação sociológica. Rio de Janeiro: Guanabara. 1987. 
- Capitalismo dependente e classes sociais na América Latina. São Paulo: Global Editora. 2009.

GONÇALVES, R. Novo desenvolvimentismo e liberalismo enraizado. Revista Serviço Social e Sociedade. São Paulo: Cortez Editora, n. 112, out./dez. 2012.

HAYEK, F. Von. O caminho da servidão. Tradução Ana Maria Capovilla, José Ítalo Stelle, Liane de Morais Ribeiro. São Paulo: Vide Editorial, 2013. HARVEY, D. O enigma do capital e as crises do capitalismo. São Paulo: Boitempo. 2011.

IAMAMOTO, M. V. Serviço Social em tempo de capital fetiche - capital financeiro, trabalho e questão social. São Paulo: Cortez Editora. 2007.

A formação acadêmico-profissional no Serviço Social brasileiro. Revista Serviço. Social e Sociedade. [online]. 2014, n.120, pp. 608-639. ISSN 0101-6628. 2014.

. Renovação e conservadorismo no Serviço Social: ensaios críticos. São Paulo: Cortez: Celats. 1994.

IAMAMOTO, M. V.; CARVALHO, R. de. Relações sociais e Serviço Social no Brasil. Esboço de uma interpretação histórico-metodológica. São Paulo: Cortez. 1985.

LE PLAY, F. Oeuvres. Paris, Plon, 1941.

LENIN, V. I. O imperialismo - fase superior do capitalismo. São Paulo: Centauro, 2008.

LUKÁCS, G. Introdução a uma estética marxista. Rio de Janeiro: Civilização Brasileira. 1978.

. Prolegômenos para uma ontologia do ser social. São Paulo: Boitempo Editorial. 2010.

2012.

. Para uma ontologia do ser social I. São Paulo: Boitempo Editorial. 2013.

. Para uma ontologia do ser social II. São Paulo: Boitempo Editorial.

MARX, K. O capital: crítica da Economia Política. São Paulo: Abril Cultural. 1983.

1984.

. O capital: crítica da Economia Política. São Paulo: Abril Cultural.

- Capítulo inédito de O capital: resultados do processo de produção imediata. São Paulo: Editora Moraes. 1985.

- Miseria de la filosofia. Respuestas a la Filosofía de la Miseria de Proudhon. México, Siglo XXI Ediciones. 1987. 
. O método da economia política. In: FERNANDES, F. (org). Marx e $\overline{\text { Engels }}$ - história. São Paulo: Ática. 1989.

. Crítica da filosofia do direito de Hegel - Introdução. In: Crítica da filosofia do direito de Hegel. São Paulo: Boitempo. 2005.

. Para a questão judaica. São Paulo: Expressão Popular. 2009.

. Glosas críticas marginais ao artigo "O rei da Prússia e a reforma social". De um prussiano. In: Lutas de classes na Alemanha. São Paulo: Boitempo Editorial. 2010.

MERTON, Robert K. Sociologia: teoria e estrutura. São Paulo: Mestre Jou. 1970.

MÉSZÁROS, I. Para além do capital. São Paulo: Boitempo. 2002.

. O século XXI - socialismo ou barbárie? São Paulo: Boitempo Editorial. 2003.

NETTO, J. P. A crítica conservadora à reconceituação. Revista Serviço Social e Sociedade. São Paulo: Cortez, ano 2, v. 5. 1981 a. $1981 b$.

. (org.). Lukács. Coleção Grandes Cientistas Sociais. São Paulo: Ática.

. Ditadura e Serviço Social: uma análise do Serviço Social no Brasil pós-64. São Paulo: Cortez. 1991.

. Capitalismo monopolista e Serviço Social. São Paulo: Cortez. 1992. (org). O leitor de Marx. Rio de Janeiro: Civilização Brasileira, 2012.

NETTO, J. P. Transformações societárias e Serviço Social: notas para uma análise prospectiva da profissão no Brasil. Revista Serviço Social e Sociedade. São Paulo: Cortez Editora, n. 50, abr. 1996.

. Pequena história da ditadura brasileira (1964-1985). São Paulo: Cortez Editora. 2014.

PARSONS, Talcott. A estrutura da ação social: um estudo de teoria social com especial referência a um grupo de autores europeus recentes. Tradução Vera Josceliyne. Col. Sociologia, v. 1. Rio de Janeiro: Vozes, 2010a.

. A estrutura da ação social: um estudo de teoria social com especial referência a um grupo de autores europeus recentes. Tradução Raquel Weiss. Col. Sociologia, v. 2. Rio de Janeiro: Vozes, 2010 b.

POPPER, Karl R. A sociedade aberta e seus inimigos. Tomos I e II. Col. Biblioteca de Cultura Humanista. Belo Horizonte: Ed. Itatiaia, 1998.

- A lógica da pesquisa científica. Tradução Leônidas Hegenberg e Octanny Silveira da Mota. 2. ed. São Paulo: Cultrix, 2013.

RICHMOND, M. E. Diagnóstico Social. Buenos Aires: Siglo XXI, 2005. 


\section{ReVigta dil paltg}

\} CRISE DO CAPITAL, NEOCONSERVADORISMO E SERVIÇO SOCIAL NO BRASIL - SILVA, J. F. S.\}

RODRIGUES, José Albertino (org.). Pareto. São Paulo: Editora Ática, 1984. (Coleção Grandes Cientistas Sociais).

SAMPAIO JÚNIOR, P. de A. Desenvolvimentismo e neodesenvolvimentismo: tragédia e farsa. Revista Serviço Social e Sociedade. São Paulo: Cortez Editora, n. 112, out./dez. 2012.

SILVA, J. F. S. da. Serviço Social: razão ontológica ou instrumental? Revista Katálysis, n. 1, v. 16, jan./jun. 20103a.

. Serviço Social: resistência e emancipação? São Paulo: Cortez Editora. 2013b.

SILVA, J. F. S. da; SANT'ANA, R. S.; LOURENÇO, E. A. de S. (org). Sociabilidade burguesa e Serviço Social. Rio de Janeiro: Lumen Juris. 2013.

TOCQUEVILLE, A. de. A democracia na América. Volumes 1 e 2. São Paulo: Martins Editora, 2014.

- Democracia y pobreza (memorias sobre el pauperismo). Madrid:

Editora Trotta, 2003.

- Lembranças de 1848 - as jornadas revolucionárias em Paris. São

Paulo: Penguin Companhia, 2011.

Recebido em 04 de maio de 2015.

Aprovado para publicação em 06 de julho de 2015 